Radio Vienna: Broadcasts by the Organization of Ukrainian Nationalists, 1938-1939

Author: Myroslav Shkandrij

Source: Kyiv-Mohyla Humanities Journal 2 (2015): 121-136

Published by: National University of Kyiv-Mohyla Academy

http://kmhj.ukma.edu.ua/ 


\title{
Radio Vienna: Broadcasts by the Organization of Ukrainian Nationalists, 1938-1939
}

\author{
Myroslav Shkandrij \\ University of Manitoba, \\ Department of German and Slavic Studies
}

\begin{abstract}
Surviving transcripts of radio broadcasts made by the OUN in 1938 and 1939 defend the Ukrainian right to an independent state and support the formation of Carpatho-Ukraine as the first step towards achieving this goal. At the same time they praise Germany for the new situation created in the wake of the Munich Agreement. The broadcasts were allowed by Germany as part of its strategy to destabilize Czechoslovakia and Poland. The strong anti-Jewish line taken by the OUN in the first months of broadcasting was likely the required payment for being allowed to broadcast. The broadcasts stopped criticizing the Soviet Union when the Molotov-Ribbentrop Pact was signed.
\end{abstract}

Key Words: Nationalism, OUN, Ukraine, interwar, Carpatho-Ukraine, Germany, Poland.

\section{(7)}

The Organization of Ukrainian Nationalists (OUN) made radio broadcasts almost on a daily basis from Vienna and Bratislava from 29 September 1938 to 22 September 1939. The transmissions focused on the Ukrainian case for self-determination and statehood, a topic that was widely discussed in the European and North American press at the time, in the wake of the Munich agreement that forced Czechoslovakia to cede territory to Germany and to establish both a Slovakian and a Carpatho-Ukrainian state. ${ }^{1}$ The transcripts of these broadcasts have survived. ${ }^{2}$ This article examines their ideological message in the political context of the late thirties.

Michael Winch, an English reporter who travelled throughout Carpatho-Ukraine during the state's brief existence (from October 1938 to March 1939), published Republic for a Day: An Eye-Witness Account of the Carpatho-Ukraine Incident in $1939 .{ }^{3}$ He suggested that there were

1 When it became part of Czechoslovakia in 1919, the territory was called Subcarpathian Rus (Pidkarpatska Rus; in Czech, Podkarpatska Rus). After gaining autonomy it called itself Carpathian Ukraine, but in English-language publications is generally referred to as Carpatho-Ukraine. See the Ukrainian Cultural and Educational Centre (Oseredok), Mykhailo Seleshko archive, OUN B3 (c) and $\mathrm{B}_{4}$ (a) Ea-4-8 and in OUN B4 (a) Ea-4 9.

The Munich agreement of 29 September 1938 forced Czechoslovakia on November 7 to recognize the desire of Slovakia for autonomy and, on the following day, that of Carpatho-Ukraine. The latter formed a government on November 11. Its first president, Andrej Bródy (who also used the Hungarian spelling Andras Bródy), was arrested by Czech authorities for secret contacts with Hungary, 
two fundamentally different approaches in Germany to the newly-formed state. The first represented the cautious official approach in Berlin, which saw the benefits of a Ukrainian irredentism centred in Carpatho-Ukraine but preferred to dampen expectations of German help. The second, according to Winch, represented the view of nazi supporters in Vienna: it favoured a quick disintegration of Czechoslovakia and creation of a Greater Ukraine. Winch reported that the government of Carpatho-Ukraine in Khust (Chust) maintained a moderate tone in its broadcasts from Bratislava, while the Vienna station "which gave unofficial Ukrainian bulletins, was violently anti-Czech and anti-Polish in tone, and every day painted the Ukrainians as heroes struggling for some intangible rights in a world of darkness and injustice." ${ }^{4}$ It is not clear whether there were in fact two sets of broadcasts. It may be that official communiqués from the Carpatho-Ukrainian government in Khust (Chust) were reported separately. However, the transcripts of the Vienna-Bratislava radio broadcasts, which were brought to Canada in 1948 by Mykhailo Seleshko, a leading OUN organizer in Germany, blended pronouncements by the Khust government, information from German, Czech, Polish and other presses, and commentaries by the OUN. The tone and content varied from day to day. All transcripts appear to have been reviewed by the OUN leader Yaroslav Baranovsky (pseudonym Makar): they contain his handwritten corrections and comments.

These broadcasts provide a unique insight into the OUN's politics at a time when it was being drawn into cooperation with Germany. They cover the period of Carpatho-Ukraine's existence, but also Germany's growing conflict with Poland in 1939, and the invasion of that

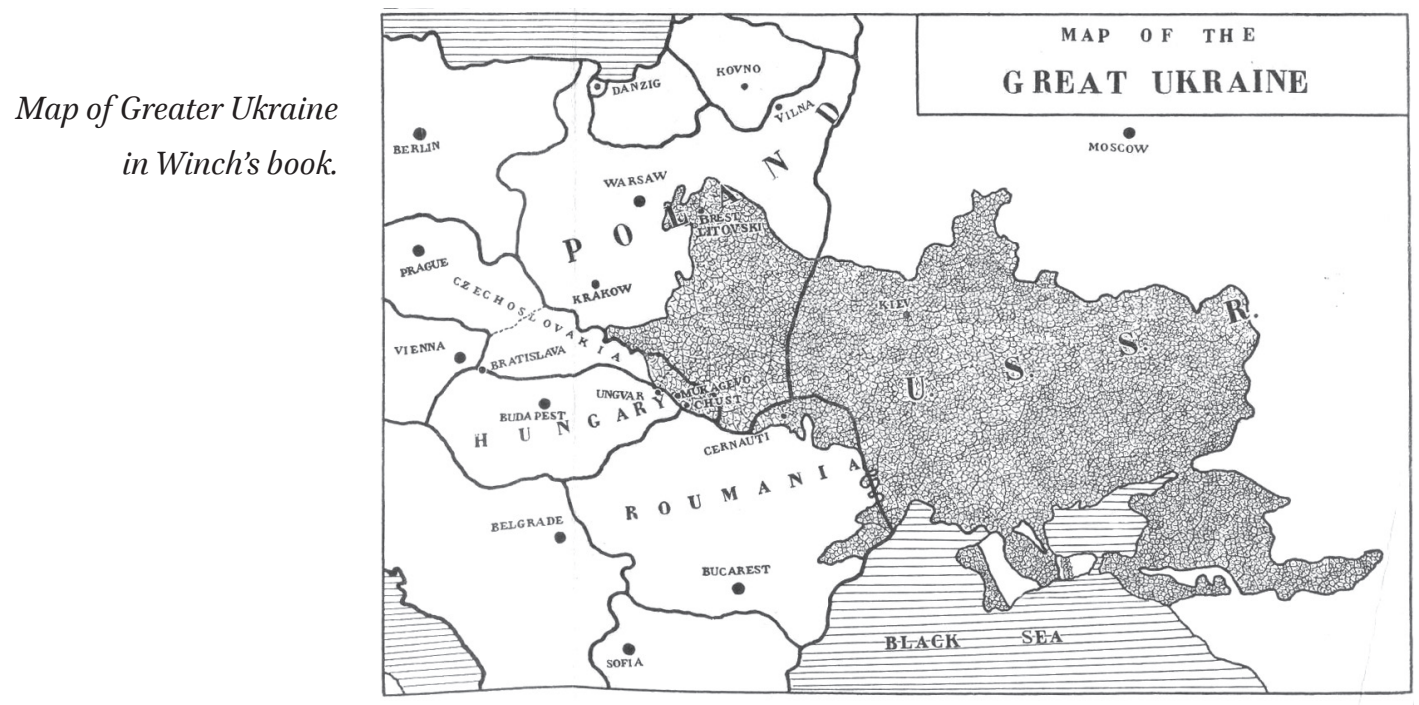

which wanted to annex the territory. On November 26 a Ukrainophile administration headed by Monsignor Avhustyn Voloshyn (Augustin Volosin), a Catholic priest, was installed. Three weeks after an arbitration in Vienna, Hungary obtained the most economically developed area in the south including the capital Uzhhorod. The capital was moved to Khust. The state was invaded by Hungary on 14 March 1939.

4 Michael Winch, Republic for a Day: An Eye-Witness Account of the Carpatho-Ukraine Incident (London: Robert Hale Limited, 1939), 28-29. 
country by Hitler and Stalin on the 1 and 17 September 1939 respectively. German military intelligence allowed the broadcasts as part of its policy of weakening first Czechoslovakia and then Poland: the transcripts contain strong criticism of both countries, but allow criticism of the Soviet Union only prior to the signing on 23-24 August 1939 of the Nazi-Soviet pact.

The Sich defends Winch's hotel against the Czechs in 1939. Photograph in Winch's book.

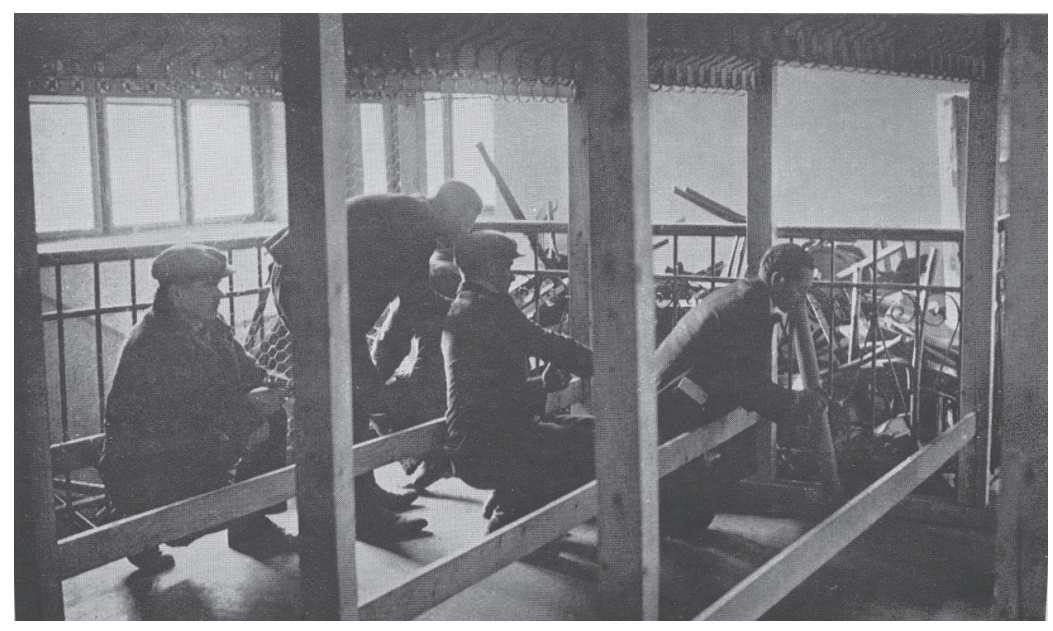

In the interwar period the government of Czechoslovakia had treated Ukrainian and other East European émigrés with considerable sympathy. However, once it realized that a Ukrainian national movement was developing strength in the Carpathian region, it began to support the Russophile population there, to open Czech schools and close down Ukrainian ones. This fuelled antagonism toward Prague among Ukrainians. When he asked a local Ukrainian whether the latter feared Germany making slaves of them all, Winch received the response:

\footnotetext{
Nothing could be worse than slavery to the Czechs. [...] Perhaps we shall be in the grip of the Germans for a bit, but it will not mean the suppression of our national feeling as does our association with the Czechs. There will be no policy of denationalization with Hitler. He appreciates our desire to unite the Ukrainian nation, for he is himself a promoter of the nationalist idea. ${ }^{5}$
}

The expectation of support was, of course, mistaken: the idea of Carpatho-Ukraine becoming a Piedmont of Ukrainian irredentism was used by Hitler to mask his real intentions in Eastern Europe. Nonetheless, Winch, like many journalists, thought at the time that a Greater Ukraine might be carved out of those territories in Poland, Romania, Czechoslovakia and Soviet Ukraine that had majority Ukrainian populations.

When Winch suggested to nationalists that coming under German control meant subjugation, he was invariably told that the new Ukrainian state would turn against Germany as soon as it was ready, and therefore "Germany would probably not make too many demands on it for she would always be aware of this danger." 6 The reporter concluded that although the nationalists were pro-independence, they were not pro-German: "They badly needed the 


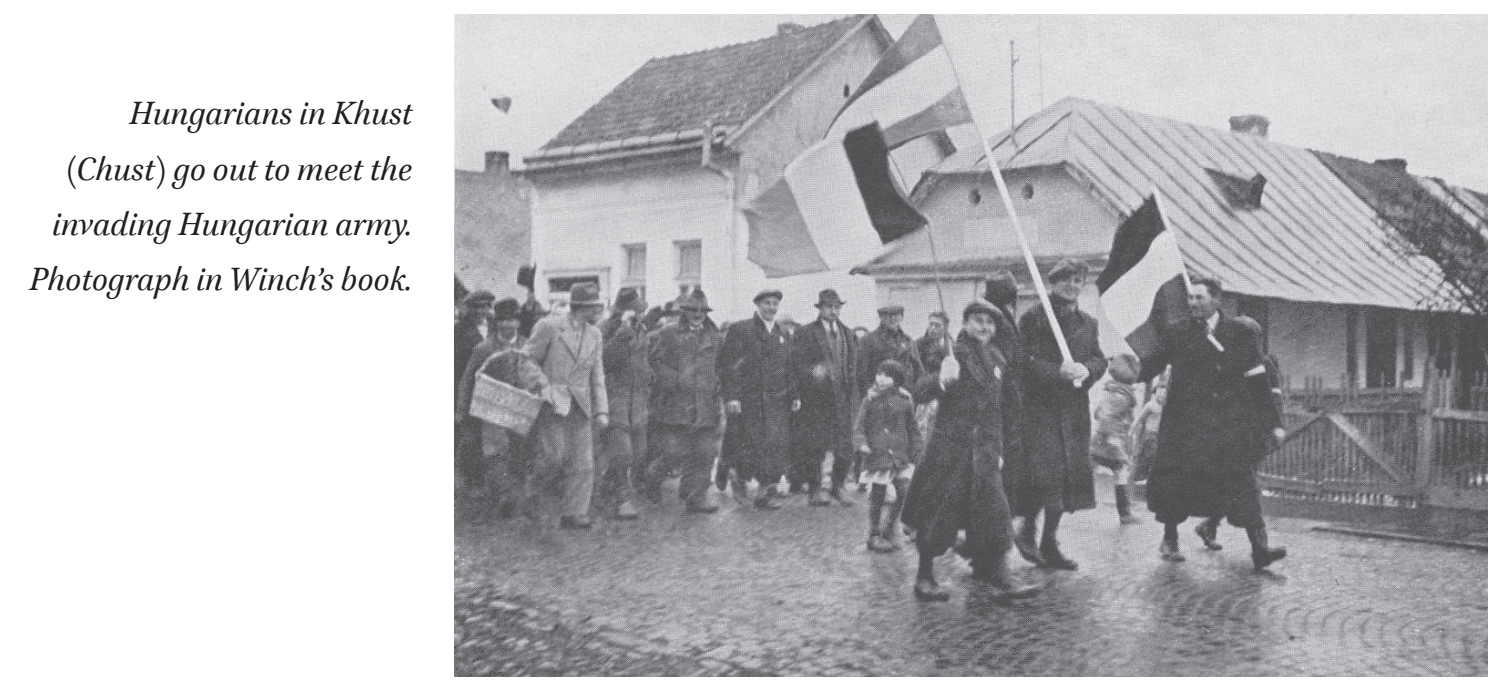

help of countries other than Germany [...] for they had no desire to become a German colony, whatever people might think." 7

Poland and Hungary were violently opposed to the idea of a Greater Ukraine and lobbied Hitler for the liquidation of the Carpatho-Ukrainian state. They sealed their borders with the latter, and blocked the railway lines, in this way paralyzing the territory's trade routes. Hungary coveted the territory, which it ruled before the First World War and which it had at the time tried to assimilate by banning or restricting the Ukrainian language, schools and organizations. By mutual agreement, in 1938-1939 the Polish and Hungarian governments conducted acts of sabotage against Carpatho-Ukraine, blowing up bridges, attacking border posts, and cutting telephone wires. Eventually, with Hitler's blessing and Poland's support, the Hungarian army invaded the territory on 16 March 1939.

British and American diplomats did not believe that a large Ukrainian state was part of Hitler's plans. A confidential report from the US embassy in Warsaw to the President on 15 December 1938 stated that Germany was silent on the subject and was observing the world's reaction to the current publicity. ${ }^{8}$ The report saw the hand of Berlin behind anti-Polish agitation in Carpatho-Ukraine, articles in Prague favouring the establishment of a "Greater Ukraine," and Ukrainian radio broadcasts from Prague, Vienna and Leipzig. ${ }^{9}$ The Soviet and Romanian embassies, on the other hand, felt that Hitler's long-term plans did include a Ukrainian state, and that the British and French were only too happy to "divert the German 'cyclone' eastward" in the hope that "an actual German thrust vis-à-vis the Soviet might spell an eventual trap for Germany." 10

Germany probably allowed the broadcasts because it wanted to have some influence over the OUN, with which it could trade for intelligence information. Moreover, the broadcasts served German purposes by criticizing and helping to undermine the governments of Prague,

Winch, Republic for a Day, 128-129.

8 Lubomyr Y. Luciuk and Bohdan S. Kordan, eds., Anglo-American Perspectives on the Ukrainian Question, 1938-1951: A Documentary Collection (Kingstone, Ont.: Limestone Press, 1987), 25.

9 Luciuk and Kordan, Anglo-American Perspectives on the Ukrainian Question, 26-27.

10 Luciuk and Kordan, Anglo-American Perspectives on the Ukrainian Question, 30. 
Warsaw and Moscow. The nationalists, in turn, benefited from the ability to promote the idea that all Ukrainians, whether under Polish, Romanian, Czech or Soviet rule, constituted a single nation that should strive for unification in an independent, sovereign state.

The legal claims to autonomous statehood put forward by Ukrainians in Poland (particularly in what is today Galicia) and Czechoslovakia (in what is today Transcarpathia) were based on promises given to Western powers by the newly-created states of Poland and Czechoslavakia when they signed the postwar treaties. The OUN's radio broadcasts anchor Ukrainian claims to statehood in these agreements. The broadcasts inform listeners that the Treaty of Versailles and subsequent ancillary agreements made numerous statements about protecting the independent existence and free development of small nations. It should be recalled that the principle of selfdetermination had already in 1916 been declared a primary consideration in any readjustment of national boundaries after the war. ${ }^{11}$ On 7 January 1918 President Woodrow Wilson had issued his famous Fourteen Points, which became the basis for the postwar treaties. He proclaimed the need for frontiers to be effected along "clearly recognizable lines of nationality" and called for "mutual guarantees of political independence and territorial integrity to great and small states alike." 12 To avoid militarism (the dogma that might is right) the League of Nations had been created with the idea of using force against any nation that refused to observe international law.

Lloyd George in his The Truth About the Peace Treaties (1938) indicated that Poland's intransigence had been a major problem for those who drew up the treaties. ${ }^{13}$ The former British prime minister, who played a major role in negotiating the treaties, commented: "Selfdetermination did not suit her ambitions. She coveted Galicia, the Ukraine, Lithuania and parts of White Russia. A vote of the inhabitants would have emphatically repudiated her dominion. So the right of all peoples to select their nationhood was promptly thrown over by her leaders. They claimed that these various races belonged to the Poles through the conquering arm of their ancestors." ${ }^{14}$ As a result, during the postwar negotiations the evidence for "racial majorities" was manipulated, and in the end the national principle was often ignored. Poland agreed that citizens who belong to racial, religious or linguistic minorities should enjoy the same treatment and security in law and in fact: "In particular they shall have an equal right to establish, manage, and control at their own expense charitable, religious and social institutions, schools and other

11 David Lloyd George, The Truth About the Peace Treaties, 2 vols (London: Victor Gollancz Ltd., 1938), 1,31 .

12 Lloyd George, The Truth About the Peace Treaties, 1, 72-73.

13 He wrote that French policy supported a greater Poland in order to weaken Germany and the existence of a large Polish vote in the United States swayed the American president. The Poles argued that in establishing boundaries one should start with the date 1772, but in fact were not satisfied even with these historical boundaries (Lloyd George, The Truth About the Peace Treaties, 2, 973). Lloyd George responded to the Polish delegation: "We won freedom for nations that had not the slightest hope of it, - Czechoslovakia, Poland, and others. [...] And we have the greatest trouble in the world to keep them from annexing the territory of other nations and imposing upon other nations the very tyranny which they have themselves endured for centuries." (Lloyd George, The Truth About the Peace Treaties, 2, 998). 
educational establishments, with the right to use their own language and to exercise their religion freely therein." ${ }^{15}$ Romania and Czechoslovakia made the same promise. ${ }^{16}$ However, none of these promises were kept. Poland refused to concede autonomy to the Ukrainians of Eastern Galicia and in 1934 repudiated promises given to minorities. In the late 193os, the government openly declared at Geneva that it must "get rid of" at least two and a half million of the three and a quarter million Jews now living within its borders and practiced discrimination against the Jewish minority. ${ }^{17}$

The OUN's broadcasts focused on the promises made in 1919-1923 and the right to selfdetermination reaffirmed in the Munich agreement, rehearsing many of the arguments that the Ukrainian government in emigration had presented over the last fifteen years. ${ }^{18}$ The predominantly Ukrainian territory of Eastern Galicia — the broadcasts pointed out — had been recognized by the Entente as an autonomous territory at the Treaty of Riga. Poland had signed the agreement but failed to implement it. At Riga Poland also received Polesie (Polissia), Chelm (Kholm) and Volhynia (13 February 1939).19 It sent General Haller's army against the Ukrainians in spite of Allied instructions that the force should not be used for this purpose (18 July 1939, 7 August 1939). The broadcasts claimed that the Ukrainians of Transcarpathia had in 1918 declared adherence to the Ukrainian state, but when Haller entered Galicia and expelled the Ukrainian army they had accepted attachment to Czechoslovakia (transcript of 29 September 1938). The Czech state on 18 November 1919 had committed itself to making the territory of Carpatho-Ukraine an autonomous part of Czechoslovakia, and had agreed within ninety days of calling its own parliament to establish a separate one for the territory (6 October 1938).

The broadcasts make it clear that Carpatho-Ukraine expected support from Germany, Britain, France, and Italy — the four powers who signed the Munich agreement. Western public opinion, it was said, had now at last becoming more favourable toward the Ukrainian cause. Hitler's recent, post-Munich speeches were described as expressing sympathy for peoples subjugated by Prague: "This confirms that the concept of Ukraine has moved from secret rooms to the light of day" (3 October 1938). Munich was described as a breakthrough for self-determination, which would now be taken into account in regulating contested European political issues (3 October 1938).

In making the case for the Carpatho-Ukrainian state, the Vienna-Bratislava broadcasts therefore combined three arguments: previously recognized statehood, broken treaty obligations, and the principle of self-determination. However, the OUN's politics went beyond

15 Lloyd George, The Truth About the Peace Treaties, 1385-86.

16 Lloyd George, The Truth About the Peace Treaties, 1365, 1375.

17 Lloyd George, The Truth About the Peace Treaties, 1396.

18 For example, Kost Levytskyi a democratic nationalist and a leading figure in the Western Ukrainian People's Republic (ZUNR) that declared independence in 1919, argued in his Velykyi zryv (Great Uprising, 1931) that Austria had de facto transferred power to Ukrainians in Galicia when the empire collapsed (Kost Levytsky, Velykyi zryv (Do istorii ukrainskoi derzhavnosty vid bereznia do lystopada 1918 r. na pidstavi spomyniv ta dokumentiv) (Lviv: Chervona kalyna, 1931), 109-10, 138-40).

19 Here and later the dates of broadcasts as marked in the transcripts are given in brackets. 
claims for limited autonomy. They insisted that self-determination for the forty-million-strong Ukrainian nation meant unification into one independent state. Almost from the first the broadcasts declared that "Transcarpathia must become a Sovereign Ukrainian State! It must become One Great Sovereign United State from Poprad and the Tatras to the Caspian Sea and the mountains of the Caucasus!" (1 October 1938).

President Wilson was regularly invoked in constructing the argument for independence: "From far beyond the seas, in the capital of American states the call of President Wilson could be heard: Away with tyranny, down with oppression! There cannot be overlord and subject nations any more! Each has the right to freedom and self-determination! And the borders and prison walls that divided one brother from another fell. Nations that had so far been oppressed and trodden under foot arose: Slovaks, Slovenes, Czechs, Croatians, Serbs, and others. And the Ukrainian people, the largest of all the oppressed has made use of that right to self-determination, has torn off its shackles and broken down the walls that have divided its brothers from one another [...] Let there be one great Ukrainian people from the Tisza to the Black Sea and the mountains of the Caucasus! May our great united Ukrainian state live and be proud!" (13 October 1938).

It was reported that on 30 January 1939 Hitler mentioned Wilson's fourteen points and stated that there could no longer be any shifting from one sovereignty to another; instead peoples were "to determine their own lives, including their political existence on the basis of the most sacred natural law" (31 January 1939). The academic Hans Koch was reported as giving a speech in Vienna in which he stated that the Entente powers had neglected the right of self-determination and allowed Ukrainian territory to be divided between four neighbours. "Thanks to Adolph Hitler," he reportedly said, Munich had given a branch of the Ukrainian people the opportunity to create its own sovereign state (5 February 1939).

Even as Hitler invaded Prague and allowed Hungary to overrun Carpatho-Ukraine, Munich was still being invoked. On the day Hungary invaded, the German press was quoted as saying that Czechoslovakia had oppressed Germans, Slovaks and Ukrainians, and had "lost the moral right to intervene in the internal affairs of Bratislava or Khust" (15 March 1939).

The broadcasts developed the argument that the Ukrainians of Carpatho-Ukraine had long suffered exploitation and oppression as a national group:

Our history, from the sixteenth century, is full of religious persecution! The Hungarian lords forced our peasants into the Calvinist faith, changed their Ukrainian surnames to Hungarian, and along with their faith our ancestors lost their nationality. The whole Tisza valley, once Ukrainian, has today been made Hungarian by force. [...] During the war our alphabet was taken away, and they wanted to change even liturgical books to the Hungarian alphabet [...] (12 October 1938).

In recent years the broadcast continued - schools had been forced to teach in the Czech language. Land had been given to immigrants from Russia, and was now being given to Jews who were moving there after being forced out of other countries (4 October 1938). All factories and banks were in the hands of Czechs, Jews and Hungarians (2 October 1938). The Prague government had invested 14 million kroner into railways over the last twenty years but not one metre of track had been built in Carpatho-Ukraine (7 March 1939). 1.6 million kroner had 
been invested in the territory over the same period, but 2 million had taken out in taxes alone (7 March 1939). 500,ooo hectares had been given to Polish colonists in areas that were already considered overpopulated (1 July 1939).

The broadcasts reported that the appearance of an autonomous Carpatho-Ukrainian state was being widely discussed in the international press. Gleb Struve, a scholar of Russian literature, had written in the London Times on 13 October 1938 that there were no Ukrainians on the territory of Carpatho-Ukraine, and that any Ukrainian movement there was "artificial." However, Charles Gaskell had in the same issue indicated the strategic importance of the territory, that over seventy percent of the population was Ukrainian, that the Czechs had settled there only in the last twenty years and numbered only 40,00o (18 October 1938). A French journalist was reported as affirming in Journal de Debats on 17-18 October 1938 that the composition of the territory was overwhelmingly Ukrainian, and that the population desired neither a return to Hungarian rule, nor Polish intervention (20 October 1938). It was reported that Hungary, Poland and the Soviet Union were all opposed to the creation of an autonomous Ukrainian state, and that the Poles and Soviets in particular greatly feared Ukrainian irredentism. In France the publicist Robert Valery-Radeau insisted that only an undivided Russia in alliance with France could resist German imperialism and contain the liberationist movement in Ukraine. Another French publicist, who presented the Ukrainian question as a German intrigue, had reportedly written: "there is no Ukraine." As evidence he indicated that the prewar Baedeker tourist guide failed to mention the country. A French parliamentarian was reported as stating that the Ukrainian national movement was "organized in Berlin" (19 February 1939). Russian monarchists writing in the Paris Vozrozhdenie (Rebirth) informed: "there is no Ukrainian language, because it is only a provincial dialect, and the only Ukrainian literary genius is Gogol, who wrote in Russian" (26 January 1939). It claimed that there were only 2,350 Ukrainians in Carpatho-Ukraine. The rest were "Russian people" (russkie liudi). Pavel Miliukov's organ in Paris Poslednie novosti (Latest News) called the appearance of the Ukrainian problem "a symphony played under Berlin's baton." In response, one of the Vienna-Bratislava broadcasts described Miliukov's group as belonging to the "demoliberal, Masonic and Jewish groupings of the Russian [moskovskoi] emigration" (26 January 1939).

Not just the OUN but most sectors of Ukrainian society in Galicia and Transcarpathia appear to have supported statehood. The Lviv newspaper Dilo supported the claims of both Galicia and Carpatho-Ukraine to political autonomy. Its editors were members of the UNDO (Ukrainian National Democratic Union), the dominant Ukrainian party in interwar Galicia, a supporter of parliamentary democracy and a participant in elections to the Polish Sejm (legislative body). Its editorials were confiscated and its articles regularly censored by the Polish government. In the United States large meetings and demonstration took place at this time in defence of Carpatho-Ukraine's autonomy. The broadcasts reported that on 9 October 1938 in New York's Edison High School over 3,ooo Ukrainians who had emigrated from this region spoke in defence of autonomy (20 October 1938). The meeting's resolution was read during one of the broadcasts (21 November 1938). It called upon the signatories of the Munich agreement to support the state, and informed that the territory's Ukrainians had in 1918-1919 expressed their desire to be united with the Ukrainian state that declared independence in 1918, and had only agreed to be part of Czechoslovakia because they had been promised autonomy (21 October 1938). 
Another line of argumentation insisted not on international agreements and political principles but on the population's strength and determination. This was clearly a reflection of the OUN's voluntaristic views. A "fierce, merciless struggle," argued one broadcast, was being waged by "interlopers" who desired Ukrainian lands. In this life-and-death struggle the side that was braver and showed more endurance would win. Ukrainians had to reply to the "steel and blood of enemies with ten-times more steel and blood! An eye for an eye! A tooth for a tooth!" (2 October 1938). The broadcasts repeatedly assured listeners that Carpatho-Ukraine "does not want foreign lands, but will not cede any piece of its own territory to enemies" (12 October 1938).

This line was more militant and intolerant of opposition than pronouncements from the government in Khust. The OUN's newspaper Narodnia volia [People's Will] was quoted as saying: "The first battle on the external political front has brought us complete victory. The next stage awaiting us is the internal political front. What does the struggle at home mean? There can only be one answer: down with internal enemies, hidden wreckers, various 'Russians' and Hungarians [...]. Many of them still sit in responsible posts and quietly use every opportunity for their purposes. The present task of our front line activists is to uncover these leeches and expose them to the light of day" (23 December 1938). The rhetoric quickly assumed an aggressive tone: "What common interests does the Ukrainian worker have with the Russian [moskovskym] worker, the Jewish foreman [nahaniach], the Russian-Jewish informer or head of a collective farm, who is sent into Ukraine by the Kremlin - Moscow or Petrograd - to extract Ukrainian riches from a land flowing with milk and honey in order to export them for a predatory, indolent Moscow to use in its own interests, for the vagabonds of the Spanish international, the committees of poor peasants who do not work, detest the labour of others and murder those among their brothers who cannot live without creating?" (23 December 1938). The importance of military resistance was emphasized. Stepan Rosokha, an OUN activist and a member of the government, stated: "The people have to be ready at all times; they have to become an armed camp" (27 December 1938).

The reports emanating from the government of Carpatho-Ukraine were far more moderate. Upon installation, the Ukrainian administration in Khust immediately began preparing for elections to its Sejm, which was to have thirty seats. It was reported that the German and Hungarian communities were each to have one representative (11 January 1939), as were the Czech and Romanian communities (27 January 1939). In the run up to the vote, which took place on 12 February, the radio's listeners learned that villages would compete with one another for the white flag, which would be run up in ridings that voted at least $98 \%$ for the single list of candidates of the Ukrainian National Association. Political parties were not banned but were forbidden to contest the election. They were required to name their representatives to what was described as a government of unity. The decision to run the election in this manner had been taken by the Prague government on 26 October 1938 as part of the post-Munich agreement.

There was a "German Party" that was "organized on national socialist principles" (4 February 1939). A member of the government, Iuliian Revai, was reported as saying that the Ukrainian National Association and the German Party shared "the same ideas." Karmazin, the leader of the German community agreed that "the age and the consonance in ideas demanded cooperation" (8 February 1939). 243,557 people voted in what was essentially a referendum. 
The Ukrainian National Association received an approval rate of 92.4\%. Most minorities voted in favour, except for the Hungarians, who were overwhelmingly opposed (14 February 1939).

Broadcasts reported that the government had made Ukrainian the state language, that Greek-Catholic and Orthodox holidays were now state holidays, that government permission was required to publish journals and the punishment for failure to comply with this regulation was between two and twelve months imprisonment (1 January 1939). The government began to reorganize the hospital system. It also announced the building of a new railway connection to bypass the blocked line through Hungary (5 January 1939). Avgust Voloshyn was reported as giving an interview to Folkischer Beobachter in which he voiced hopes for economic cooperation with Germany, stated that German had been introduced as a subject in higher school classes, and announced that easier travel to schools in Germany was planned (29 December 1938).

The press in the first months of 1939 was full of reports of Hungarian terrorist groups whose actions aimed at destabilizing the state. There was no mention of Polish groups doing the same, perhaps because of German censorship, although it is now known that the Poles and Hungarians cooperated in an extensive operation to destroy infrastructure. The government announced the building of a radio transmitter and the establishment of a government publishing house (19 January1939). It stated that it wished to establish state-funded universal education, a system of old age security, state credits to peasants that would enable them to develop their farms. It also wanted an annulment of loans at usurious interest rates, and an end to speculation on the stock exchange (2 February 1939). However, the economic situation was deteriorating, and a conflict with Prague flared up when General Prchala was appointed to the government without Khust being consulted, a move that was considered a breach of the agreed-upon constitution (28 January 1939).

After the Carpatho-Ukrainian state ceased to exist the broadcasts turned their attention to Poland. They described Warsaw's harassment of Prosvita reading society activists. A deputy head of Prosvita had been beaten and forced to burn 300 books (10 May 1939). In two villages the director of Polish schools had demanded a list of individuals who had borrowed books from the Prosvita library. Prosvita's directors were often taken to court and charged with keeping illegal literature, even though these books were published legally in Poland. Reportedly the police were particularly upset with books devoted to the history and geography of Ukraine, because Poles "want to prevent young Ukrainian villagers from understanding their great past and the extent of a Ukrainian space" (15 June 1939).

It was reported that the Polish government was attempting to isolate Volhynia from nationalist influences. The Polish post office refused to deliver Ukrainian periodicals from Galicia and made private trips to the territory difficult: workers and even tourists were being prevented from travelling there (30 June 1939). Meanwhile the polonization of Volhynia was being accelerated. Over 200 colonies were organized for the reeducation of village children, who had supposedly been "ruthenianized" and needed "revindicating" (returning to their original faith and language). Many cooperatives and private shops were being closed down (11 May 1939). Similar efforts to prevent the Ukrainian movement from putting down firmer roots were reported in the Chelm, Podlachia and Lemko regions (15 May 1939). The successful dairy cooperative Maslosoiuz was shut down in some towns, and efforts were made to close the cooperative Tsentrosoiuz by raising taxes and preventing exports. Polish groups had smashed 
the windows of Maslosoiuz stores and disrupted its work (12 June 1939). Although it is not clear whether all these reports are accurate, the accelerated polonization campaign, persecution of Ukrainian activists, closing of cooperatives under various pretexts, and the quarantining of some territories have been documented by scholars. The liberal and democratic press published similar stories whenever allowed to do so by the censors.

The OUN's radio broadcasts reported that the Polish Sejm had passed a law limiting the holdings of Orthodox lands. A parish could have a maximum of 40 hectares, and a bishopric 15 . Land in excess of this limit could be bought by the state and redistributed to Polish colonists. In this way 60,00o hectares had been taken without compensation from the Ukrainian Orthodox church over the last two decades (2 June 1939). In one broadcast Ukrainian complaints were summarized as follows:

Poland wishes to destroy Ukrainians not only through physical terror and by making impossible the cultural, economic, religious and even sporting development of Ukrainians, but also attempts to distort the soul of the people in all possible ways. [...] One should first underline that seven million Ukrainians do not have their own university, and Polish authorities cause them as many difficulties as possible when they try to enrol in Polish universities. Large schools in Ukrainian villages are Polish or at best utraquist [bilingual] with Polish teachers, who in brutal fashion try to pour into the Ukrainian child a Polish soul. At the same time Ukrainian teachers are resettled in the centre of Poland. There are examples of Ukrainian children being forced by Polish teachers to attend Roman Catholic religious instruction, to sing Polish patriotic songs and to pray in Polish. At the same time Polish teachers forbid Ukrainian children to pray and sing in Ukrainian. The spontaneous reaction of Ukrainian children in the face of beatings, isolation and even prison, is not to be broken but to look their torturers [...] in the eye and to say: "We want a Ukrainian school with a Ukrainian teacher" (10 June 1939).

On 16 June a Roman Catholic priest reportedly said during a public meeting that there never was or would be "a Ukraine in Galicia." He claimed that over the last fifteen years not Ukrainians but Poles were the mistreated group in the eastern lands. He stated that Galicia was "oil, grain, salt, forests, rivers and streams [and] coal deposits," and that Poles "have stopped pandering to Ukrainians and are now organizing their relations in accordance with Polish state interests." The struggle against Ukrainians was being waged in three areas: religion, economics and education. He was pleased to note that in the Stanislaviv (Stanislaw) diocese in the previous year 251 Greek Catholic priests had been punished (16 June 1939). The broadcast added that according to Western press reports around a thousand Ukrainian priests were in prison at the time.

The repression in Poland that followed the liquidation of Carpatho-Ukraine was often violent. The broadcasts reported the torture of political prisoners by electric shock, and the fact that deaths in police custody were often treated as suicides (11 August 1939). A massacre of 300 people handed over to the Poles by Hungarians on 20 March was reported. The broadcast was unable to confirm whether the victims were deserters or people who had legitimately crossed the border (7 July 1939). In the Volhynia, Polissia and Chelm regions, 6oo Prosvita reading rooms were forcibly closed (21 June 1939). It was reported that 114 Ukrainian churches had been pulled down, and their icons and books destroyed (15 July 1939). The Roman Catholic 
Church, the military and revindication commissions participated in these acts. A unification of the calendar had been proposed, but Ukrainians objected that this should then also apply to Moslems, Jews and Karaites. Wanton destruction of homes was common at the time, and several examples were given (20 June 1939). The broadcasts indicate that out of 3,000 Ukrainian schools that existed in 1922 just over 100 remained by 1939 (12 August 1939). The systematic destruction of Ukrainian institutions is not disputed by contemporary scholars, although the figures vary. A recent study has estimated that the number of unilingual Ukrainian schools in Galicia fell from 3,60o in 1918 to only 450 in 1939 (Portnov).

The broadcasts also reported that Polish colonization was taking place along a line stretching from Przemyśl through Lviv to Ternopil, with the intention of splitting Galicia in two. A similar action was being conducted in Volhynia with the goal of separating Ukrainians from the border with Soviet Ukraine (15 August 1939).

Listeners were told that many of these reports had been confirmed by non-Ukrainian newspapers, such as the Dutch Het Natsionale Dagblad and the Polish Kurier Warszawski. The latter had complained that "one cannot be a Slav if one oppresses another Slav" (17 August 1939). In its final weeks on the air the radio station complained that Poles had allowed their "historical pretensions" and "imperialist mission" (which included the dream of ruling from sea to sea) to push them into applying state terror against minorities (21 August 1939). The economy, it was said, was collapsing, speculation was on the rise, and the black market was making life miserable (24 and 31 August 1939). Poland had proven incapable of organizing its own internal life because it had bitten off too much at Versailles and saddled itself with a huge minority population. This millstone made inevitable the turn to state terror and the move to destroy national movements. The Norwegian press was reported as saying that "Poland's misfortune was in having demanded too much in 1919" (6 September 1939).

Some news items were taken from the German press communiqués, but many came from Ukrainian sources and the OUN's own news bureaus. Many of the conclusions harmonized with statements by independent commentators like Winch and Lloyd George. However, the broadcasts departed from commentary in the mainstream Ukrainian and Western press in a number of respects.

The first was the defence of Germany, which, as has been seen, occurred within a discourse criticizing the post-Versailles order. The broadcasts insisted that Hitler had guaranteed the borders of Carpatho-Ukraine (6 November 1939). The OUN tried to align the Ukrainian cause with Germany and the fascist states. One transcript quoted La Vita Italiana as saying that the European conflict was "between the demo-plutocratic-Jewish-Masonic creatures of Versailles and the principle of national self-determination of fascist states," or in slightly different terms "between the Jewish-Asiatic bolshevik international and these states" (17 February 1939).

The attempt to contrast Hitler's Germany with everything Soviet led to a juxtaposition of religion with atheism. Hitler was reported as saying that no one had been persecuted in Germany for religious views. The broadcast then described authoritarian regimes as recognizing God. In Spain General Franco had spoken of God and the Fatherland; in Portugal Salazar had recognized the importance of religion; Mussolini had made an oath to God the first sentence in the fascist oath; and the national socialists had included a call for God's help in their oath (25 February 1939). 
Closely aligned with Berlin's propaganda was the line that the Soviet Union had intended to make Carpatho-Ukraine a military base (3o September 1938). The "Prague union with bolshevik Russia foresaw the role of a military base for Carpatho-Ukraine, for the advance of red Moscow into Europe, something that they, the Ukrainians, as natural defenders of European culture in the face of Asiatic barbarism and as implacable opponents of communism, would never allow" (1 October 1938). It was said that after Prague and Moscow signed a pact of mutual support in 1935, the Comintern had conducted subversive work in Carpatho-Ukraine, which it viewed as a bridge linking the Soviet Union with Western Europe:

Annually over a dozen paid communists were sent from Carpatho-Ukraine to the Ukrainian SSR for so-called instruction. These students were kept there in strict isolation from the external world, lest, God forbid, they were able to see the 'heaven' that Jewish-Russian leaders of the 'world revolution' had constantly told them about. Nonetheless, after returning to Transcarpathia, many of these 'students' escaped the Jewish-Russian narcosis and the 'world proletariat', came out forcefully against communism and began struggling against the new enslavement of the working people (9 October 1938).

The second major departure from mainstream reporting was the development by the OUN of a much stronger anti-Jewish line. The broadcasts used the formula "Jews-bolsheviks" with frequency, especially in the early weeks. It was reported that the government was attempting "to lessen Jewish influence on economic life by supporting Ukrainian enterprises and Ukrainian capital" (18 February 1939). The OUN had taken an increasingly strong antisemitic line since 1937, a symptom both of its hope for German support and of the degenerating political atmosphere in Europe. Broadcasts described the Jews of Transcarpathia, a population of around 100,000, as follows:

For their faithfulness and devotion in service to the Czechs the Jews obtain, especially in Carpatho-Ukraine, all sorts of concessions for taverns, in which they turn an already poor population to drink and in this way make it even more dependent on them for almost all trade and other state monopolies, for all sorts of public works, supplies and so on. In short, the Jews have a special privileged position in the Czech administration of Carpatho-Ukraine. In return they repay the Czechs. They propagate the Czech idea in Carpatho-Ukraine, they are informers for the Czech police against the Ukrainian liberation movement, which they fight against with all methods available to them - sometimes treacherously, sometimes by sending people to Czech prisons, or by denying a citizen all means of existence. It is strange that the peasants and working population fear Jews more than the Czech gendarmerie, because the economic policies of the Czech occupation in Carpatho-Ukraine has deliberately made the population financially almost completely dependent on Jews. Only a Jew can buy and sell. If someone lacks the money with which to buy, a Jew gives credit at usurious rates, and only to whoever has goods or land, which a Jew can take from the poorest worker of peasant through the available government powers. Jews struggle against profitable manufacturing cooperatives and private businesses of Ukrainian institutions by all means, including illegal ones [...] (9 October 1938). 
The broadcasts described opposition to Carpatho-Ukraine's autonomy as the work of agitators who were Jews, Moscowphiles or Marxists in the pay either of communists or Prague (2o October 1938).

Occasionally broadcasts included a "lecture" (referat), which was a propaganda piece by the OUN. One such lecture included on 31 December 1938 was devoted to Jews: "Among the minorities in Ukraine there are 3.25 million Jews (on the basis of statistics from 1931). In Ukraine their role throughout history has been to strengthen an enemy order. Now they serve the bolsheviks. The orendars (leaseholders) of the lords' estates and tavern-keepers, who often kept the keys to churches, supported the foreign lords in exploiting the Ukrainian people. In the same way they now oppose the liberation struggle of the Ukrainian people and stand with Moscow, bolshevism and its satellites. The entire leadership and organizational apparatus of the "Communist Party of Western Ukraine" is Jewish. In Central and Eastern Ukrainian lands Jews and Russians [moskaliamy] work as GB [secret police] agents, informers and countless commissars to destroy Ukrainian freedom fighters." The lecture described Jews as "self-servers [shkurnykiv], materialists, egoists, who demoralize and corrupt the peoples of the world, a people without a heroic view [heroism] of life, without a great idea that would drive them to self-sacrifice, a people that knows only personal profit and pleasure in the satisfaction of the lowest instincts, that wants to corrupt the heroic culture of fighter-nations." The phrasing here is almost exactly the same as was used a few months later in an article by Yaroslav Stetsko, an indication that he may have been the author. ${ }^{20}$ The lecture ends: "Bolshevism, which the Jews in Ukraine now serve, is a product of the Russian [moskovskoho] Asiatic, and the main enemy of Ukraine is Moscow, not the Jews, who are helpers of Moscow and therefore have to be opposed to that extent" (31 December 1938). This same phrasing would be repeated in the propaganda of the OUN-B (Bandera wing) in 1941.

$20 \quad$ In May 1939 German-Polish relations deteriorated rapidly as Hitler demanded that Danzig (Gdańsk) be ceded to Germany. On 8 May 1939 Yaroslav Stetsko, a leading member of the OUN(B), perhaps with a view to pleasing the Germans, published the following in the Canadian newspaper Novyi shliakh under the pseudonym Zynovii Karbovych: In the past they were orendars [leaseholders] of landowners' estates and tavern-keepers who not infrequently held the keys to churches; as stewards of the Poles they exploited the people. Now in similar manner they have come out against the Ukrainian people's liberation struggle, in aid of Moscow, bolshevism and its satellites. The entire leadership and organizational apparatus of the 'Communist Party of Western Ukraine' is composed of Jews. [...] As agents of the GPU, spies and numerous commissars, Jews and Russians in Eastern Ukraine are together destroying Ukrainian liberation fighters. Jewry is helping Moscow's bolshevism and, on the other side [of the border] the rest of Ukraine's enemies. It has captured trade in its hands and lives on Ukrainian lands practicing deceit, exploitation, serving Ukraine's enemies. It is a nation of profiteers, materialists, egoists, that demoralizes and undermines the peoples of the world, a nation without a heroics of life, without a great idea inspiring devotion, a nation that knows only personal gain and the pleasure of satisfying its lowest instincts, and wants to undermine the heroic culture of others. [...] The main struggle is against Moscow and bolshevism; it is against Jews only to the extent that they help the enemies of the Ukrainian nation and try to exploit and undermine the Ukrainian people. 
In the early weeks of 1939 similar comments on the contemporary political role being played by Jews were broadcast frequently. On 3 January listeners were informed that "Jewish propaganda in collusion with reactionary supporters of the popular front is attempting to change the world's respect for Germany into a hysterical fear of the war psychosis [...]" On 27 January it was reported that a meeting of Jews had decided to send abroad a delegation in order to discuss with other Jews the possibility of emigrating from Carpatho-Ukraine. The broadcast commented: "The delegation should be wished complete and immediate successes" (27 January 1939).

In later broadcasts anti-Jewish comments occurred less often. Instead, the formulaic phrase describing the enemy became "Russian bolshevik" (28 June 1939). Within the OUN there were those who spoke out against the expression of antisemitic views, and warned that Hitler's racism and his plan for Eastern Europe, which had already been expressed in Mein Kampf, boded ill for Ukrainians. The broadcasts did indeed cautiously distance themselves from some German policies. Germany, it was said, could mount an exhibition such as the Heim ins Land (meaning leave the city for the village) because this was possible in an industrialized country. However, Ukraine, a primarily agricultural nation, had to put forward the opposite slogan: from village to city, conquest of the city! (3 March 1939). This message was repeated the following day. "To the cities" was presented as a counterslogan to Hitler's "Blut und Boden" message and Mussolini's "faithfulness to the earth" (4 March 1939). On 6 March the broadcast again ended by saying: "the cities in Eastern Europe are the political centres of the people" (6 March 1939). Moreover, when providing information the broadcasts made a distinction between German and Ukrainian communiqués and sources. One German press release, for example, was reported as informing that squares in Carpatho-Ukraine had been named after Adolph Hitler in locations where Germans were a majority (27 December 1938). By presented this without comment, and indicating that the information came from a German source, the broadcast suggested that it had been required to convey this uninspiring news.

On 22 March it was mentioned that witnesses had seen Jews pointing out to invading Hungarians houses in which the Sich militia (the largely OUN-led police force of CarpathoUkraine) was located (22 March 1939). However, much of the violent anti-Jewish rhetoric had disappeared by then. The formula "Russian-Jewish bolsheviks" occurred for the last time in the broadcast of 25 April 1939. Criticism of Hungary also disappeared at this time, while criticism of Poland, by contrast, took centre stage. From the day that the Soviet army crossed the border into Poland until the final broadcast on 22 September the reports consisted exclusively of German communiqués and were identified as such: the broadcasts became laconic accounts of troop movements with no commentary.

While the Vienna-Bratislava station was allowed to operate, broadcasters made the case for an independent Ukrainian state, perhaps persuaded that an invasion of the Soviet Union would occur. Although manipulation by Berlin is evident, the authors of the transcripts did not merely follow nazi directives but developed an argument for statehood based on international agreements, the principle of self-determination, and the idea of justice for small or oppressed nations. However, the flattery of Hitler and alignment with Germany discredited the OUN and, for many observers, the cause of independence itself. Contemporaries and later historians have argued that the Carpatho-Ukrainian state and the OUN were used by Germany to destabilize 
Czechoslovakia and Poland, and that the autonomous state and the nationalist movement were then cast aside when they had served this purpose. The transcripts of the broadcasts suggest that this was indeed the case. Except for some above-mentioned veiled references, the broadcasts contain no criticism of Germany, even after Hungary had been allowed to invade and crush Carpatho-Ukraine. The transcripts also indicate that the OUN adopted a much stronger anti-Jewish line at this time, in all likelihood as part of the required "payment" for radio transmissions, military training, and promises of future support.

\section{Bibliography}

Levytsky, Kost. Velykyi zryv: Do istorii ukrainskoi derzhavnosty vid bereznia do lystopada 1918 r. na pidstavi spomyniv ta dokumentiv [The Great Upheaval: Toward the History of the Ukrainian State from March to November of 1918 on the Basis of Memoirs and Documents]. Lviv: Chervona kalyna, 1931.

Lloyd George, David. The Truth About the Peace Treaties. 2 vols. London: Victor Gollancz Ltd., 1938.

Luciuk, Lubomyr Y., and Bohdan S. Kordan, eds. Anglo-American Perspectives on the Ukrainian Question, 1938-1951: A Documentary Collection. Kingstone, Ont.: Limestone Press, 1987.

Mykhailo Seleshko archive, Ukrainian Cultural and Educational Centre (Oseredok), Winnipeg.

Portnov, Andrii. Nauka uvyhnanni:Naukovai osvitnia diialnistukrainskoiemihratsiivmizhvoiennii Polshchi (1919-1939) [Science in Exile: Academic and Educational Activity of the Ukrainian Emigration in Interwar Poland, 1919-1939]. Kharkiv: KhIFT, 2008.

Winch, Michael. Republic for a Day: An Eye-Witness Account of the Carpatho-Ukraine Incident. London: Robert Hale Limited, 1939. (Translated into Ukrainian as Vinch, Maikl. Odnodenna derzhava: Svidchennia anhliiskoho ochevydtsia pro podii Karpatskoi Ukrainy. Kyiv: Tempora, 2012.)

\section{9}

Myroslav Shkandrij has degrees from Cambridge (BA) and Toronto $(\mathrm{PhD})$ universities, and is a professor of Slavic Studies at the University of Manitoba. His books on Ukrainian literature and cultural politics include Modernists, Marxists and the Nation: The Ukrainian Literary Discussion of the 1920s (Edmonton: Canadian Institute of Ukrainian Studies, University of Alberta, 1992), Russia and Ukraine: Literature and the Discourse of Empire (Montreal and Kingston: McGillQueen's University Press, 2001), Jews in Ukrainian Literature: Representation and Identity (Yale University Press, 2009), and Ukrainian Nationalism: Politics, Ideology and Literature, 1929-1956 (Yale University Press, 2015). He helped to curate the art exhibitions "Phenomenon of the Ukrainian Avant-Garde, 1910-1935" (Winnipeg and Hamilton, 2001), "Futurism and After: David Burliuk, 1882-1967" (Winnipeg, 2008), and "Propaganda and Slogans: The Political Poster in Soviet Ukraine, 1919-1921" (New York, 2013). His translations into English include Mykola Khvylovy's The Cultural Renaissance in Ukraine: Polemical Pamphlets (1986) and Serhiy Zhadan's Depeche Mode (2013). 